\title{
МЕТОДИ ВІЗУАЛІЗАЦІЇ У МЕДИЧНИХ І БІОЛОГІЧНИХ ДОСЛІДЖЕННЯХ
}

\section{Методи візуалізації у медичних і біологічних дослідженнях}

В. Д. Дідух, Ю. А. Рудяк, О. А. Багрій-Заяць, Л. В. Наумова

Тернопільський національний медичний університет імені І. Я. Горбачевського МОЗ України

Резюме. У роботі розглянуто сучасні методи візуалізації (ПЕТ, МРТ, КТ, ОФЕКТ), які використовують у медичних та біологічних дослідженнях.

Мета дослідження - показати ефрективність сучасних методів візуалізації для доклінічних і клінічних досліджень in vivo для знаходження новоутворення в органі, проведення своєчасної діагностики онкологічних захворювань та здійснення дияеренціації злоякісних і доброякісних новоутворень.

Результати. Доклінічна візуалізація in vivo на будьякому рівні організації організму надзвичайно ефективна, завдяки якій мінімізується кількість дослідних тварин, яких використовують, і можна оцінити стан кісток скелета, м'яких тканин, внутрішніх органів, кровоносних судин і пересреричних нервових волокон у різних тварин, включаючи риб, земноводних рептилій, савців і комах. Гібридні методи дослідження дозволяють локалізувати довільну анатомічну структуру чи патологічний прочес.

Висновки. У cmammi розглянуто можливості візуалізації медико-біологічних систем із застосуванням MPT, КT, ПЕТ і гібридних систем: ПЕT/КT, ПЕТ/MPT, СТ/ПЕT.

Ключові слова: МРТ; КТ; ПЕТ; ОФЕКТ.

\section{ВСТУП}

Розробка електронних і протонних прискорювачів, радіодіагностичних гамма-камер, рентгенівських комп'ютерних томографрів, магнітно-резонансних томограсрів, лазерних, ультразвукових та інших медико-фрізичних установок породили основні методи медичної візуалізації: сонографрію (УЗД), рентгенологію магнітно-резонансну і комп'ютерну томографрію, гамма-сцинтиляцію, однофротонну емісійну комп'ютерну томографрію (ОФЕКТ), позитронну емісійну томографрію (ПЕТ), гібридні системи ОФЕКТКТ і ПЕТ/КТ, КТ - лінійний прискорювач [1-4].

Серед методів медико-біологічної візуалізації особливе місце займають ПЕТ, КТ, МРТ,
Visualization methods in medical and biological research

V. D. Didukh, Y. A. Rudyak, O. A. Bagrii-Zaiats, L. V. Naumova

I. Horbachevsky Ternopil National Medical University e-mail: bagrijzayats@tdmu.edu.ua

Summary. The paper deals with modern imaging methods (PET, MRI, CT, SPECT) used in medical and biological research.

The aim of the study - to demonstrate the effectiveness of modern visualization methods for preclinical and clinical studies in vivo, for finding neoplasms in the organ, conducting timely diagnostics of cancer and performing differentiation of malignant and benign tumors.

Results. Preclinical in vivo imaging at any level of the organization of the body is extremely effective, which minimizes the number of experimental animals used, and can evaluate the condition of the skeletal bones, soft tissues, internal organs, blood vessels and peripheral nerve fibers in various animals, including fish, amphibian reptiles, mammals and insects. Hybrid methods of rer search allow to localize any anatomical structure or pathological process.

Conclusion. The article considers the possibilities of visualization of medical and biological systems using MRI, CT, PET and hybrid systems: PET/CT, PET/MRI, ST/PET.

Key words: MRI; CT; PET; SPECT.

про що свідчить велика кількість публікацій [5-10]

Метою дослідження було показати ефективність сучасних методів візуалізації для доклінічних і клінічних досліджень in vivo для знаходження новоутворення в органі, проведення своєчасної діагностики онкологічних захворювань та здійснення диореренціації злоякісних і доброякісних новоутворень.

\section{РЕЗУЛЬТАТИ ТА ОБГОВОРЕННЯ}

У середині XX ст. Нільс Бор, один із творців квантової теорії, писав: «Жоден результат біологіч- 
ногого дослідження не может бути описаний інакше, як на основі понять фрізики і хімії».

Епохальні відкриття і дослідження рентгенівського випромінювання В. Рентгеном, створення О. Лоуренсом циклотрона, сцинталіційного сканера Б. Кассеном, кругового ПЕТ сканера Е. Фелпсом і Е. Хоффраном, гамма-камери Х. Енджером, розроблення методики магнітно-резонансної томографії (МРТ) П. Лаутербуром і П. Менссрілдом та рентгенівської комп'ютерної томографрії (КТ) А. Кормаком і Г. Хаунсорілдом, зробили революційні перетворення у медицині й біології та створили нові методи візуалізації медико-біологічних систем (рис. 1).

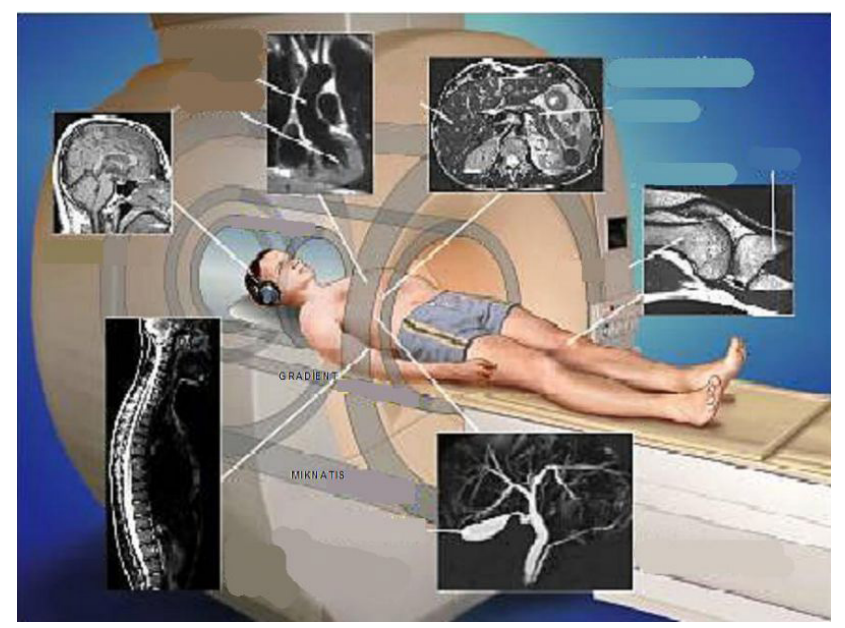

Рис. 1. Зображення томограм, отриманих за допомогою магнітнорезонансної томографрії [1].

Останнім часом інтенсивно розробляють гібридні методи діагностики, коли один метод діагностики пухлин і патологій доповнює інший.

Доклінічні й клінічні методи дослідження

На відміну від КТ і МРТ, ракову пухлину на ранніх їі стадіях може зафіксувати лише ПЕТ. Тому для отримання повної картини необхідно суміщення двох методик: ПЕТ знаходить місце пухлини, а КТ чи МРТ дають прив'язку до відповідного органа.

Діагностична цінність ПЕТ/КТ-діагностики полягає у можливості виявлення пухлинних новоутворень при відсутності клінічних ознак і отримати 3D-зображення біохімічних процесів, що відбуваються у тканинах організму людини [2-4].

Метод МРТ дозволяє візуалізувати будову різних внутрішніх органів людського тіла у вигляді набору зображень окремих зрізів (перетинів) $з$ їх контрастуванням по протонній густині, по Т1 (час спін-ґраткової релаксації) і Т2 (час спін-спінової релаксації), забезпечуючи диореренційну діагностику патологій різних внутрішніх органів. Отримані зображення зберігаються в базі даних і можуть бути проаналізовані на екрані монітора або виведені на друк з використанням паперу або прозорої плівки.
При проходженні через досліджуваний об'єкт рентгенівські промені послаблюються через поглинання енергії та розсіювання. Зміну інтенсивності рентгенівського випромінювання при проходженні через тканину можна описати рівнянням:

$$
I=I_{0} e^{-\mu d},
$$

де: I - інтенсивність випромінювання після проходження об'єкта, I - інтенсивність випромінювання, що падає $\mu$ - коефріцієнт повного лінійного поглинання для тканини, $d$ - це відстань, через яку пройшло випромінювання.

Рентгенівські промені, проходячи через досліджуваний об'єкт, нерівномірно поглинаються і реєструються системою детекторів. Вони генерують в детекторах електричні сигнали й обертаються у тому ж напрямку як і рентгенівський випромінювач, проте знаходяться навпроти нього.

Чим більша інтенсивність випромінювання, тим сильніший електричний сигнал. Досліджуваний зріз тканини можна уявити розділеним на набір рівних за обсягом елементів - вокселів.

Величина сумарного коефріцієнта поглинання при проходженні випромінювання через ряд вокселів дорівнює:

$$
\mu=\mu_{1}+\mu_{2}+\ldots+\mu_{N 1}+\mu_{N}
$$

де: $\mu_{1}, \mu_{2}, \ldots, \mu_{N}-$ коефріцієнти поглинання відповідними вокселями.

Розглянемо шар об'єкта, що складається із чотирьох рівновеликих вокселів, через який проходить рентгенівське випромінювання (рис. 2).

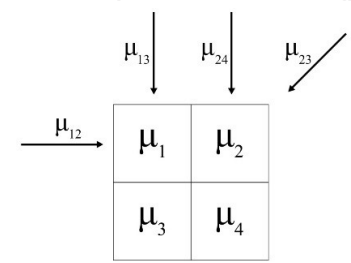

Рис. 2. Проходження рентгенівського випромінювання через об'єкт.

Інтенсивність рентгенівського випромінювання, що пройшло крізь досліджуваний об'єкт, можна обчислити за фрормулою:

$$
I=I_{0} e^{-\mu d}=I_{0} \exp \left(-\mu_{1} d-\mu_{2} d-\ldots \mu_{N} d\right) .
$$

Сумарні коефіцієнти поглинання для вокселів можна записати у вигляді системи рівнянь:

$$
\begin{aligned}
& \mu_{1}+\mu_{2}=\mu_{12} ; \\
& \mu_{2}+\mu_{3}=\mu_{23} ; \\
& \mu_{1}+\mu_{3}=\mu_{13} ; \\
& \mu_{1}+\mu_{4}=\mu_{14} .
\end{aligned}
$$

Розв'язуючи дану систему рівнянь, знаходимо коефіцієнти поглинання для кожного вокселя. Зокрема, для $\mu_{1}$ і $\mu_{3}$ отримуємо:

$$
\begin{aligned}
& \mu_{3}=\left(\mu_{12}-\mu_{23}+\mu_{13}\right) / 2 ; \\
& \mu_{3}=\left(\mu_{13}-\mu_{12}+\mu_{23}\right) / 2 .
\end{aligned}
$$

Кожному вокселю на отриманому зображенні відповідає певний окремий піксель, яскравість яко- 
го відображає коефріцієнт поглинання рентгенівських променів відповідним векселем [5].

У сучасних томографрах цифрова матриця отриманого зображення найчастіше має розмірність 512×512 чи 256×256 пікселів.

Серед методів клінічної діагностики особливе місце займає однофотонна емісійна комп'ютерна томографрія (ОФЕКТ), суттєво відрізняється від рентгенівської КТ за клініко-діагностичними цілями. Якщо рентгенівська КТ досліджує структурно-морфологічні, анатомічні зміни органів, то за допомогою ОФЕКТ завдяки введеним в організм радіофармпрепаратом (РФП) пошарово досліджують фрункціональний стан органів і систем.

Принцип ОФЕКТ полягає в отриманні серії сцинтиграм при обертанні одного чи декількох детекторів томографра навколо повздовжньої осі тіла пацієнта, якому введений радіофармпрепарат. Проекції зображення, отримані за повний оберт детектора, опрацьовуються комп'ютером, який реконструює відповідні зрізи.

У 1931 р. Отто Варбург, німецький біохімік і фрізіолог, один із видатних вчених XX ст. у галузі цитології, досліджуючи окисно-відновлювальні процеси у живій тканині встановив, що злоякісні пухлини відрізняються підвищеним рівнем споживання глюкози.

Майже через півстоліття почали вимірювати локальний рівень метаболічного споживання глюкози в мозку щурів, вводячи дезоксиглюкозу помічену радіоактивним ізотопом фртора ${ }^{18} \mathrm{~F}$. Майкл Фелпс у 1979 р. запропонував вимірювати локальний рівень метаболічного засвоєння глюкози людьми, вводячи дезоксиглюкозу, мічену радіоактивним ізотопом ${ }^{17} \mathrm{~F}$ (фртородезоксиглюкоза), період піврозпаду якого становить 109,8 хв.

Ці праці заклали основи позитронної емісійної томограсрії.

Значного застосування методи отримання 30бражень за допомогою радіофрармпрепаратів набули 31948 р., коли Енсел і Ротблат розробили методику поточкової реєстрації зображень щитоподібної залози.

Застосовуючи метод позитронно-емісійної томографрії, який винайшов у 1951 р. Л. Ренне, можна не лише одержувати зображення внутрішніх органів, а й оцінювати їх фрункцію і метаболізм. Так, за допомогою позитронної томографії вдається виявляти хворобу на ранньому етапі, ще до прояву клінічних симптомів.

У процесі позитронної емісійної томографрії (ПЕТ) в організм людини вводять невелику кількість радіоактивного препарату, наприклад ${ }^{17} \mathrm{~F}$, період піврозпаду якого становить 1,2 хв. Після цього радіоізотоп, переміщаючись судинами організму, досягає, наприклад, тканини головного мозку чи серцевого м'яза, де, розпадаючись, випромінює позитрон $\beta^{+}$, який, взаємодіючи із електроном найближчого атома, утворює атом позитронія. При його розпаді електрон і позитрон анігілюють, утворюючи два протилежно напрямлених гамма-кванти, які реєструються зовнішніми детекторами, які кільцеподібно розташовані навколо досліджуваного об'єкта.

Коли гамма-промені взаємодіють з кристалами сцинтилятора, вони за допомогою електронних пристроїв перетворюються в електричні сигнали і програмне забезпечення ПЕТ видає інорормацію у вигляді зображень. Особливу роль позитронно-емісійна томограсрія відіграє в онкології, кардіології і неврології, де рання діагностика захворювань особливо важлива.

Поєднання КТ і однофротонної емісійної комп'ютерної томографрії (ОФЕКТ) дозволяє при накладанні зображень точно визначити знаходження новоутворення в органі, проводити своєчасну діагностику онкологічних захворювань, здійснювати дисеренціацію злоякісних і доброякісних утворень.

Відзначимо, що чутливість ПЕТ на 12 порядків вища порівняно з ОФЕКТ, і ПЕТ є фрункціональним методом, тоді як КТ чи МРТ - анатомічні. При різних захворюваннях в більшості випадків порушення метаболізму передують морфологічним, таким, що відображаються структурними методами візуалізації: ультразвукове дослідження (УЗД), комп'ютерна томографрія (КТ), магнітно-резонансна томографрія (МРТ).

Метод соноеластограсрії дозволяє оцінити щільність тканин за допомогою УЗД - за величиною деформації поверхнево розташованих органів (щитоподібна і молочна залози, лімфатичні вузли), зумовленої фрізичними чинниками. Так, відбиті від досліджуваних органів хвилі при періодичній дії на них ультразвукового датчика відображають на екрані монітора стан еластичності (щільності) тканин [6].

Одним із напрямків діагностики, що найбільш стрімко розвивається, є томотерапія, яка полягає в об'єднані КТ і лінійного прискорювача.

Комбінація ПЕТ і КТ- чи МРТ-сканерів дає змогу отримати зображення місця розташування порушень метаболізму в організмі. За допомогою ПЕТ можна виявити вогнища запалення чи ракові пухлини, а за допомогою КТ - визначити їхню локалізацію (рис. 3).

Поєднання КТ і односротонної емісійної комп'ютерної томографрії (ОФЕКТ) дозволяє при накладанні зображень точно визначити знаходження новоутворення в органі, проводити своєчасну діагностику онкологічних захворювань, здійснювати диференціацію злоякісних і доброякісних утворень. 


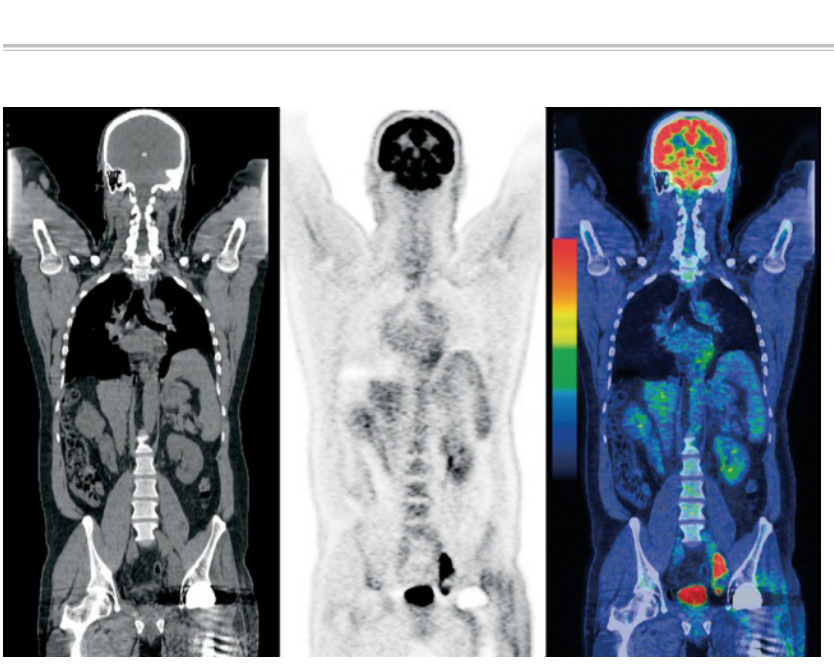

Рис. 3. Послідовні зображення КТ, ПЕТ і ПЕТ/КТ [7].

Упродовж останнього десятиліття спостерігається інтерес до in vivo-досліджень гризунів (мишей, щурів) із застосуванням МРТ, СТ, ПЕТ і гібрідних систем: ПЕТ/КТ, ПЕТ/МРТ, СТ/ПЕТ (рис. 4).

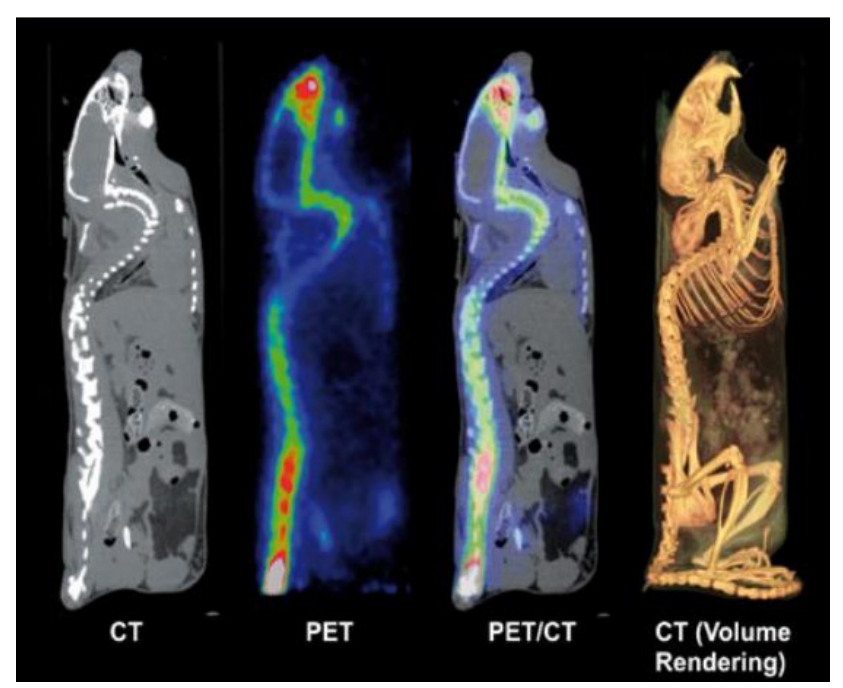

Рис. 4. Типове зображення миші за допомогою різних методів візуалізації: зліва направо: КТ, ПЕТ-зображення, ПЕТ/КТ-зображення, об'ємне відображення КТ [8].

Для гризунів магнітно-резонансна техніка дозволяє отримувати дуже високу просторову роздільну здатність (100 мікрон і менше). Залежно від вартості томографра величина магнітного поля змінюється від 0,5 до 9,4 Т. Магнітно-резонансний томографр із діаметром отвору більшим за 30 см зображений на рис. 5.

\section{СПИСОК ЛІТЕРАТУРИ}

1.https://omr.by/diagnostika-raka/vse-vidyrentgenologicheskoj-diagnostiki/magnitno-rezonansnayatomografiy?

2. Застосування поєднаного пет-кт-дослідження в діагностиці онкологічних захворювань / О. М. Клюсов, М. М. Фірсова, Д. С. Осинський [та ін.] // Онкологія. 2012. - T. 14, № 1. - С. 55.

3. Juweid M. E. Positron-emission tomography and

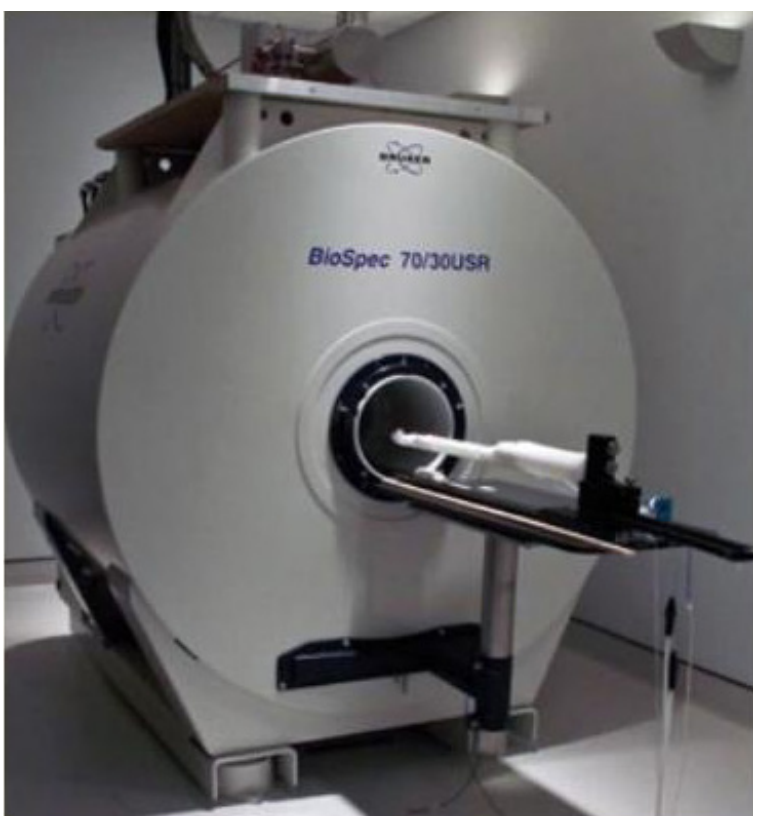

Рис. 5. Типова MR-система для дрібних тварин [9].

Одним із найпоширеніших методів дослідження тварин $є$ комп'ютерна томографрія. Роздільна здатність КТ-сканерів сягає десятки мікрон, які мають велике поле зору, що дозволяє просканувати тварину впродовж однієї хвилини.

За допомогою ПЕТ проводяться фрункціональні молекулярні дослідження на маленьких тваринах, таких, як миші, щури, аж до клітинного рівня, щоб отримати результати на спрощених людських моделях до прямого дослідження на пацієнтах.

Доклінічна візуалізація in vivo на будь-якому рівні організації організму надзвичайно ефективна, завдяки якій мінімізується кількість використовуваних дослідних тварин, і можна оцінити стан костей скелета, м'яких тканин, внутрішніх органів, кровоносних судин і периферичних нервових волокон у різних тварин, включаючи риб, земноводних рептилій, ссавців і комах. Гібрідні методи дослідження дозволяють локалізувати довільну анатомічну структуру чи патологічний процес [10].

\section{ВИСНОВКИ}

У статті розглянуто можливості візуалізації медико-біологічних систем із застосуванням МРТ, КТ, ПЕТ і гібридних систем: ПЕТ/КТ, ПЕТ/МРТ, СТ/ПЕТ.

assessment of cancer therapy. N. Engl. J. Med. - 2006. Vol. 354. - P. 496-507.

4. Overview of the clinical effectiveness of positron emission tomography imaging in selected cancers / K. Facey, I. Bradbury, G. Laking, E. Payne // Health Technol. Assess. - 2007. - Vol. 11 (44).

5. Черняев А. П. Физические методы визуализации в медицинской диагностике : учеб. пособие I А. П. Черня- 
ев, Д. В. Волков, Е. Н. Лыкова. - М. : ООП физического фракультета МГУ, 2019. - С. 42.

6. Дзюба О. М. Соноеластограсрія в діагностиці зав хворювань репродуктивної системи : огляд літератури та власні спостереження / О. М. Дзюба. - ДУ «Інститут педіатрії, акушерства та гінекології АМН України» Акушерство. Гінекологія. Генетика. - 2016. - Т. 2, № 3. C. $39-41$.

7. https://teleradiologia.ru/

\section{REFERENCES}

1.https://omr.by/diagnostika-raka/vse-vidyrentgenologicheskoj-diagnostiki/magnitno-rezonansnayatomografiy?

2. Klyusov OM, Firsova MM, Osinskiy DS, Oleynichenko OG, Kholodna AV, Lola OI [Application of the combined five-CT-study in the diagnosis of cancer]. Onkolohiia. 2012;14(1): 55. Ukrainian.

3. Juweid ME, Cheson BD. Positron-emission tomography and cancer therapy evaluation. N Engl J Med 2006;354: 496-507.

4. Facey K, Bradbury I, Laking G, Payne E. Overview of the clinical effectiveness of positron emission tomography imaging in selected cancers. Health Technol Assess 2007;11(44).

5. Chernyaev AP, Volkov DV, Lykova EN Physical imaging methods in medical diagnosis [Физические методы
8. Nuclear Physics for Medicine / Faiçal Azaiez, Angela Bracco, Jan Dobeš [et al.]. - Chapter II Medical imaging. 2014. - P. 67

9. Nuclear physics for medicine / Faiçal Azaiez, Angela Bracco, Jan Dobeš [et al.]. - Chapter II Medical imaging. 2014. - P. 68

10. Возможности визуализации при воспроизведении экспериментальных онкологических моделей у мелких животных / В. А. Печатникова, А. П. Трашков, М. А. Зелененко [и др.] // Педиатр. - 2018. - Т. 9. - № 4. - С. 105.

визуализации в медицинской диагностике]. Moscow: Moscow State University; 2019. Russian.

6. Dziuba OM [Sonoelastography in the diagnosis of diseases of the reproductive system]. Akush Hinekol Henetyka. 2016;2(3): 39-41. Ukrainian.

7. https://teleradiologia.ru/

8. Faiçal Azaiez, Angela Bracco, Jan Dobeš, Ari Jokinen,Gabriele-Elisabeth Körner, Adam Maj, Alexander Murphy,Piet Van Duppen. Nuclear physics for medicine. 2014:

9. Faiçal Azaiez, Angela Bracco, Jan Dobeš, Ari Jokinen,Gabriele-Elisabeth Körner, Adam Maj, Alexander Murphy,Piet Van Duppen. Nuclear Physics for Medicine; 2014.

10. Pechatnikova VA, Trashkov AP, Zelenenko MA Possibilities of visualization in reproduction of experimental oncological models in small animals. Pediatr. 2018;9(4): 105. Russian. 